\title{
Sequence Stratigraphy of Organic-Rich Rocks in the Niger Delta
}

\author{
Benson Akinbode Olisa and Abiola Adekunle \\ The Federal University of Technology, Akure, Nigeria. \\ (Department of Applied Geophysics) \\ DOI: $10.31364 / S C I R J / v 9 . i 10.2021 . P 1021886$ \\ http://dx.doi.org/10.31364/SCIRJ/v9.i10.2021.P1021886
}

\begin{abstract}
Total organic carbon (TOC) analysis from well logs is combined with sequence analysis to develop a model for marine accumulation of organic-rich rocks in the Niger Delta. Pologbene-001 is selected for the analysis. Four sequences of HTB are recognized. The first is at a depth $9120(2780 \mathrm{~m})$. The second HTB is at depth $9125 \mathrm{ft}(2781 \mathrm{~m})$. The HTB units were recognized by the combined characteristic patterns of gamma ray (GR), resistivity and sonic logs. TOC continuous sampling identified the system tracts, transgressive system tract (TST), lowstand system tract (LST), highstand system tract (HST) and the condensed sections. There are two possible areas for sedimentation, the marine and nearshore environments. The marine is devoid of oxygen whereas the nearshore is oxygenated. The marine sedimentation is recognized geophysically by high resistivity and transit-time whereas the reverse is the case in the nearshore.
\end{abstract}

Keywords: Transit-time, total organic carbon (TOC), stratigraphy, system tract.

\section{Introduction}

The understanding of total organic carbon (TOC) zonation within sequence stratigraphy is valuable for correlation in source rock studies.

Geologic data recorded in drill holes constitute data sets in which each observation is identified by its position in the vertical sequence. In analyzing data of the drill hole, it is necessary to identify distinct, internally homogeneous and positionally contiguous subsets within the profile. Their recognition and identification provide insight into the variability pattern of the raw data which might, in turn, lead to interpretations related to the existence of distinct contributing populations (e. g. lithologic units, biozones) or to the occurrence of distinct events (e. g. formation tops).

Oil-prone source rocks comprise sediments that are rich in organic carbon and contain organic material sufficiently hydrogen rich to convert mainly to oil during thermal maturation (Creaney and Passey, 1993). The organic materials that are generally richest in hydrogen include marine plankton, freshwater algae, spores, pollen, leaf curticle, tree resin and anaerobic bacterial. These materials are oil-prone and are classified as type I and II kerogen. The depositional environments are different and can be divided into marine and non-marine.

www.sciri.org

(C) 2021, Scientific Research Journal

http://dx.doi.org/10.31364/SCIRJ/v9.i10.2021.P1021886

This publication is licensed under Creative Commons Attribution CC BY. 
Gas-prone, organic rich rocks contain hydrogen-poor organic matter (type III kerogen) and tend to occur predominantly in the delta plain/lagoonal environment.

Previous sequence stratigraphic studies had been sedimentological with difficulty of correlations and TOC sequence studies is resisted to other basins

e. g. North Sea. Attempt is made to extend the analysis to the Niger Delta and carryout regional correlation. While there is a welldefined log response of organic rich rocks in these other basins, in the Niger Delta, the organic response to well logs is poorly defined on the logs.

\section{Depositional Environments of Source Rocks and Kerogen Types}

A simplified classification of oil-prone organic-rich rocks with the basins in which they occur is outlined in Table 1. Gas- prone source rocks contain hydrogen poor organic matter (type III) and tend to occur predominantly in the delta plain/lagoonal environment.

Based on depositional environments of organic-rich rocks, sediments can be divided into type I and type II organic matter types. Type I organic matter has very high TOC (increase resistivity and sonic in the opposite direction) while type II organic matter has low TOC (resistivity and sonic tends to zero values). Type I is found at the distal end of marine environment and type II is found at the proximal end. Type I organic matter has high resistivity and transit time (Figure 1).

\section{Geology of the Niger Delta}

The Niger Delta is located on the Gulf of Guinea, between longitudes $5^{0} \mathrm{E}$ to $8^{0} \mathrm{E}$ and latitudes $3^{0} \mathrm{~N}$ to $5^{0} \mathrm{~N}$ (Figure 2).

The Niger Delta consists of three formations in ascending order namely, Akata, Agbada and Benin Formations. Akata Formation is a time-transgression, thick marine shale, sit atop on Upper Cretaceous sedimentary sequence (Benesh et al. 2014). The shale is believed to be one of the major source rocks for hydrocarbons. Above the Akata Formation lies the Agbada Formation. This Formation is Eocene to Pleistocene in age and is believed to be the dominant petroleum-bearing unit in the Niger Delta. The Agbada Formation is recognized based on high and low gamma ray readings because of intercalations of shales and sands (Short and Stauble, 1967). The Benin Formation overlay the Agbada Formation. It is entirely continental sands. The gamma ray is generally low.

\section{Previous work}

Determination of organic-rich rocks in sedimentary basins had been described by Passey et al 1990. This methodology is adopted in this work to calculate total organic carbon (TOC) from sonic and resistivity logs. The method employs the overlaying of properly scaled

www.sciri.org

(C) 2021, Scientific Research Journal

http://dx.doi.org/10.31364/SCIRJ/v9.i10.2021.P1021886

This publication is licensed under Creative Commons Attribution CC BY. 
sonic log on resistivity curve. In water-saturated organic-lean rocks, the two curves parallel each other. However, in hydrocarbon reservoir or organic rich rocks, the two curves separate.

Creaney et al. 1993 combined sequence stratigraphy with TOC analysis from well logs, cores and cuttings to develop a model for TOC accumulation in marine source rocks. The discovered that routine well profiling of TOC in marine source rocks has revealed that recurrent patterns in the vertical distribution of TOC occur (HTB unit) can be explained with sequence stratigraphic concept.

\section{Materials and Methodology}

Logs: Sonic, resistivity and gamma ray logs.

Source rock thickness at least 100ft thick.

Source rock value: TOC values above $2 \%$ by weight.

Well Pologbene-001

\section{Methodology}

\section{Vertical Distribution of Organic Matter}

During routine identification and quantification of source rocks, it was apparent that marine organic-rich shales are often composed of discrete sedimentary units, which have the highest TOC values near their bases, Creaney et al (1993). Within a single unit, the organic carbon content gradually decreases upwards to background levels at, or near $1 \%$ by weight. These relatively high TOC, sharp-based units occasionally occur singularly, but more typically they can be stacked one on top of each other.

In analysing the facies, both the well log and organic matter characteristics were used. In a sequence of the source rocks, the maximum flooding surface has the highest TOC. At this surface, the gamma-ray, the sonic and resistivity values should be very high, but the density values should be very low.

\section{Results and discussion}

\section{Pologbene-001}

Figure 3 shows the responses of a source rock to well logs in Pologbene-001. The figure shows that the responses are poor compared to other basins e. g. Uinta and North Seas basin (Figure 4).

The MFS is the point where TOC is the highest in the sequence. To analyse each of the subsection the log analysis was carried out.

There are four HTB units in the section.

The first HTB is at a depth $9120(2780 \mathrm{~m})$ (Figure 5) has the following characteristics.

www.sciri.org

(C) 2021, Scientific Research Journal

http://dx.doi.org/10.31364/SCIRJ/v9.i10.2021.P1021886

This publication is licensed under Creative Commons Attribution CC BY. 
The gamma ray curve fines upward, the transit time increases upward, resistivity curve increases upward and the density curve increases downward. This subsection has sonic and resistivity curves in the same direction, a typical HTB unit. It is a mature source rock. All these characteristics for the well logs are correct for this subsection.

Tables 2 and 3 show the well $\log$ and TOC values of the section respectively and Figure 6 shows the log response of the interval. There are four sequences (subsections) established using maximum flooding surface (MFS).

The Total organic carbon (TOC) characteristics are as follows (Table 2):

GR (TOC) increases upward, transit time (TOC) increases upward and the density (TOC) increases downward. This is correct condition for the maximum flooding surface.

The second HTB is at depth $9125 \mathrm{ft}(2781 \mathrm{~m})$ has the following characteristics:

The gamma ray log shows coarsening upwards, and the resistivity and sonic curve exhibit HTB, increases upward (Table 3).

\section{System Tracts}

Figure 7 shows identification of system tracks by TOC continuous samplings. The condensed section is identified by fining and coarsening upward sequence. The lowstand is above the sequence boundary while the highstand is on top.

\section{Conclusion}

Total organic carbon (TOC) distribution was used in sequence stratigraphic interpretation in Pologbene-001. The TOC is distributed in a predictable vertical sequence with high TOC at the top and low TOC at the base. The depositional environments are oil-prone organic-rich and gas-prone organic lean source rocks at their respective positions. The condensed section coincided with fining upwards sequence with a high TOC at the top. Resistivity and transit-time curves have a relationship with the TOC content which were then to identify the marine and non-marine (nearshore) environments. The depositional environments were lowstand, highstand, transgressive system tracts.

\section{Reference}

[1] Creaney S. and Q. R. Passey, (1993), Recurring Patterns of Total Organic Carbon and Source Rock Quality within a Sequence Stratigraphic Framework: Bulletin American. Association of Petroleum Geologist, v. 77, p. $386-401$

[2] Passey Q. R., S. Creaney, J. B. Kulla, F. J. Moretti and J. D. Stroud, (1990), A Practical 
Model for Organic-Richness from Porosity and Resistivity Logs: Bulletin American. Association of Petroleum Geologist, v. 74, no. 12, p. $1777-1794$.

[3] Nathan P. Benesh, Andreas Plesch, and John H. Shaw (2014), Geometry, kinematics, and displacement characteristics of tear-fault systems: An example from the deep-water Niger Delta: Bulletin American. Association of Petroleum Geologist, V. 98, P 465-482
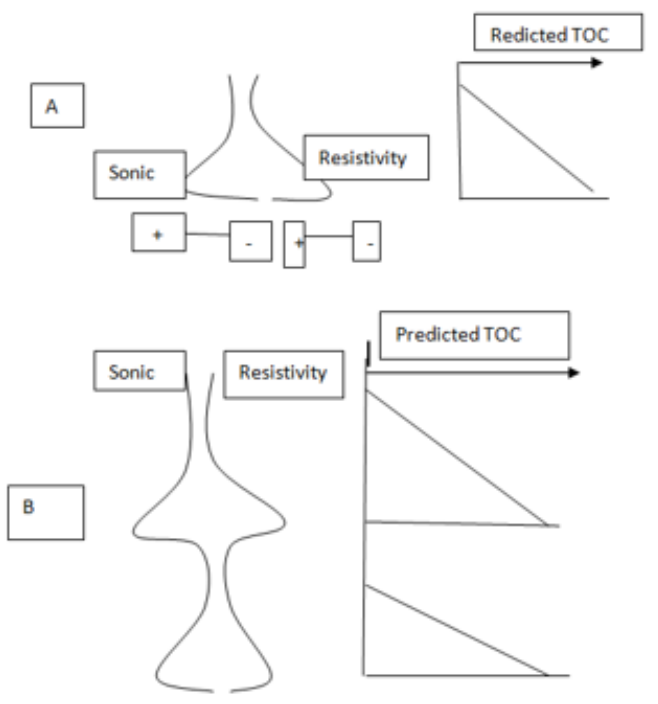

Figure 1: Schematic $\Delta$ Log R and Resulting Predicted TOC Profile (Creaney et al.,1993).

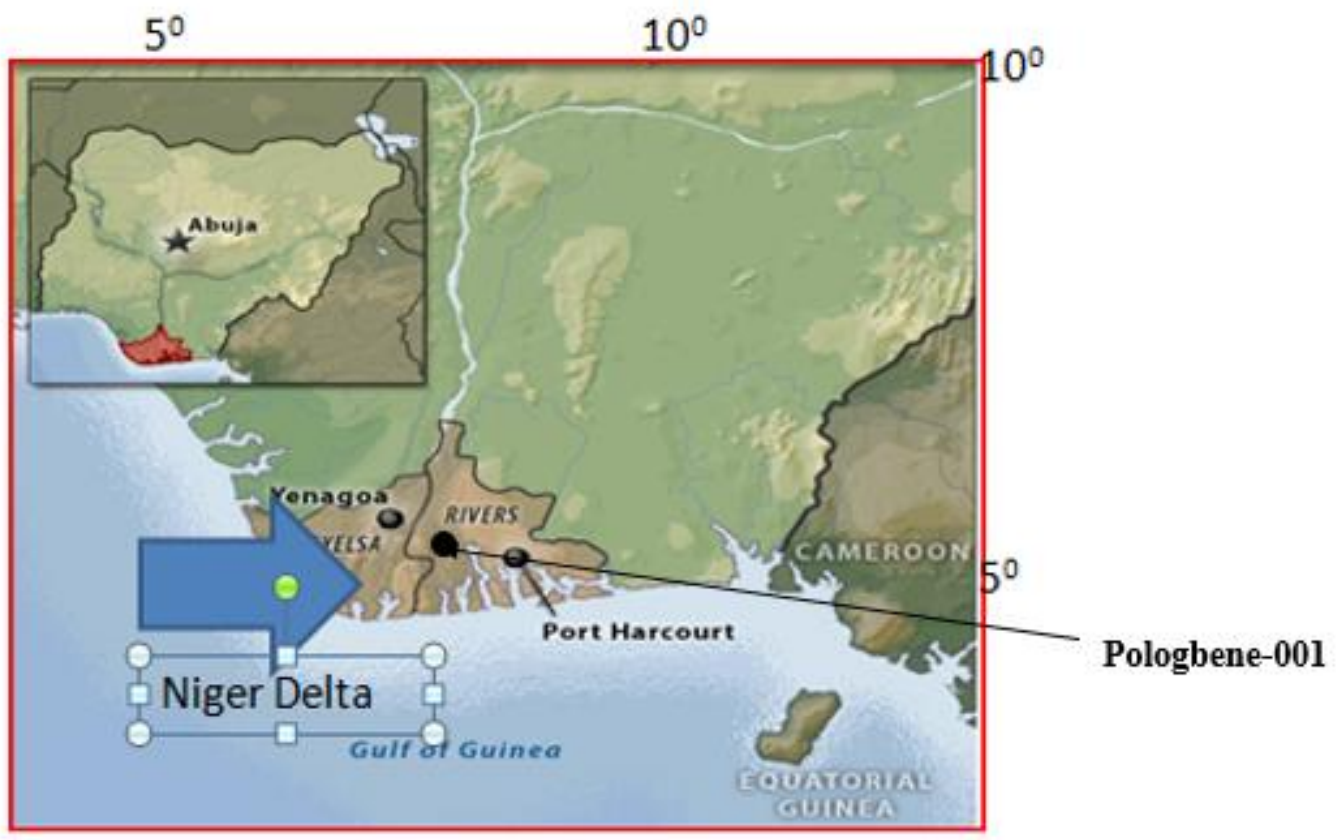

www.scirj.org

(C) 2021, Scientific Research Journal

http://dx.doi.org/10.31364/SCIRJ/v9.i10.2021.P1021886

This publication is licensed under Creative Commons Attribution CC BY. 
Figure 2 Location Map of the Niger Delta

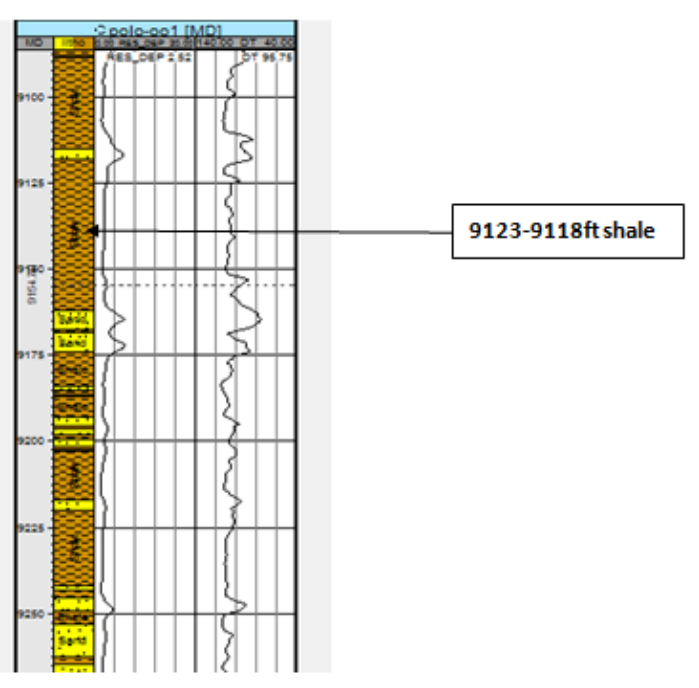

Figure 3: Resistivity and Sonic log Response of Organic-Rich Shales at Pologbene-001

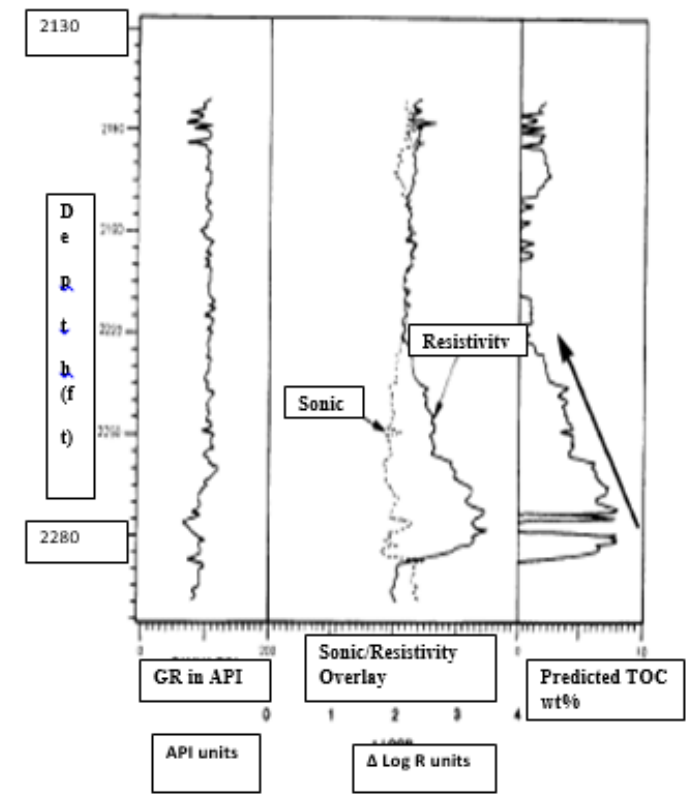

Figure 4: Decreasing upward unit from the Toarcian of Paris basin.

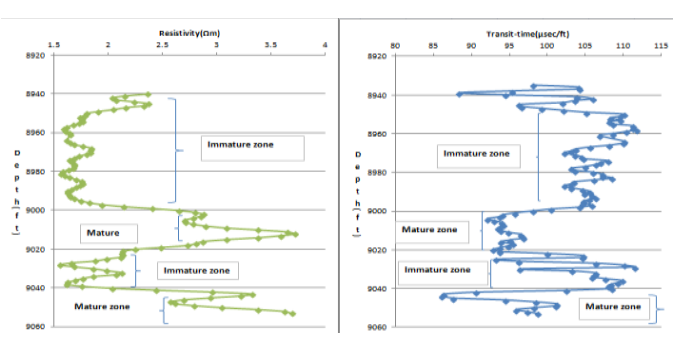

Figure 5: Plot of Resistivity $(\Omega \mathrm{m})$ and transit-Time ( $\mu \mathrm{sec} / \mathrm{ft})$ against depth at Pologbene-001

www.scirj.org

(C) 2021, Scientific Research Journal

http://dx.doi.org/10.31364/SCIRJ/v9.i10.2021.P1021886

This publication is licensed under Creative Commons Attribution CC BY. 


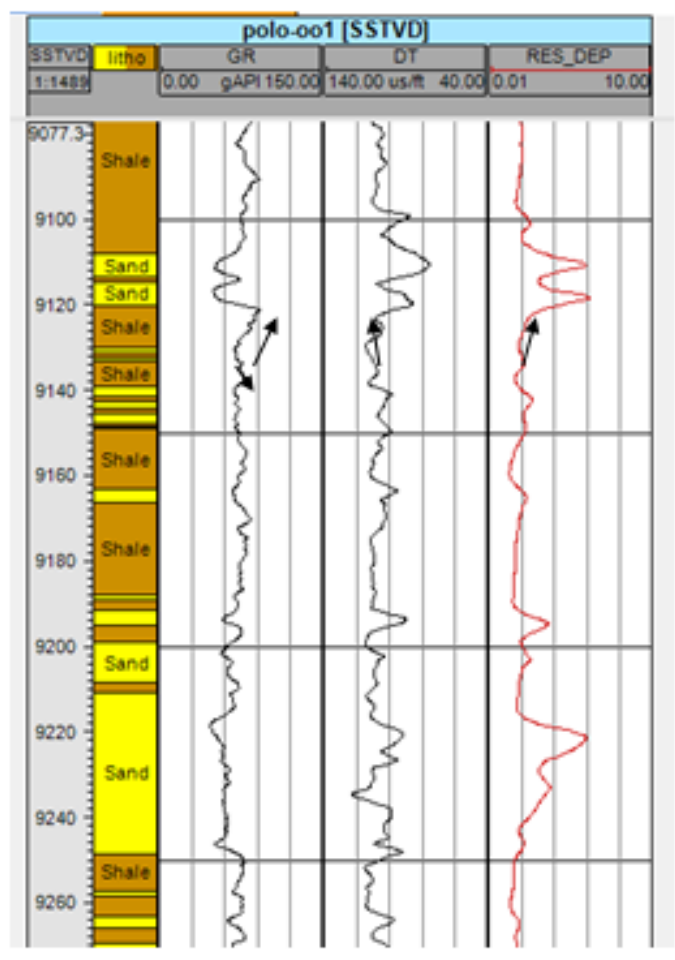

Figure 6: Log Signature of Section 9123-9118 ft (2781-2779 m) at Pologbene-001

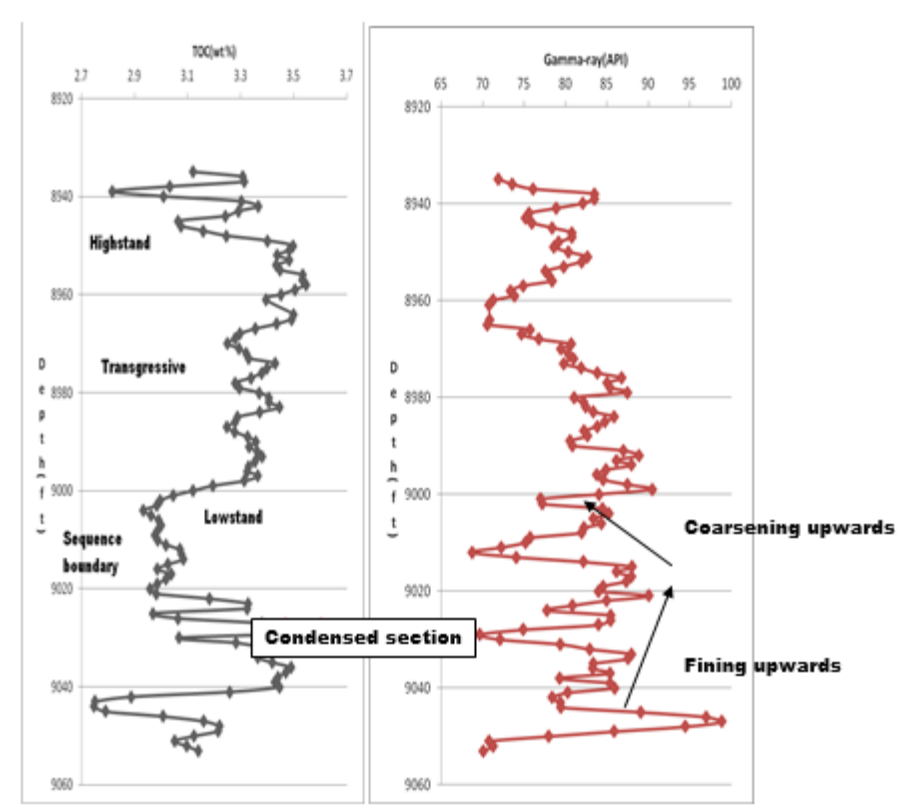

Figure 7: Subsurface Sequence Tracts.

Table 1: Classification of oil-prone organic-rich rocks 


\begin{tabular}{|c|c|c|}
\hline Depositional Environments & Kerogen Type & Basin of Occurrence \\
\hline Low-Oxygen Lakes & $\begin{array}{c}\text { Type II kerogen. Marine Plankton } \\
+ \text { Anaerobic Bacteria. }\end{array}$ & Middle East (Jurassic) \\
\hline Low-Oxygen Coal Swamps and & $\begin{array}{c}\text { Type II or III Kerogen. Spores, } \\
\text { Pollens, Curticles, Fresh water } \\
\text { Lagoonal Muds }\end{array}$ & Niger Delta, Nigeria (Tertiary) \\
& Algae, Vitrinite, inertinite, + & \\
\hline Large-low Oxygen lakes & Type I Kerogen. Fresh water Algae \\
& + Anaerobic bacteria. & Uinta Basin, United States of \\
& & America (Eocene) \\
\hline
\end{tabular}

Table 2: Sequences (using Well Log) in Shale Section 9161-9118ft at Pologbene-001 


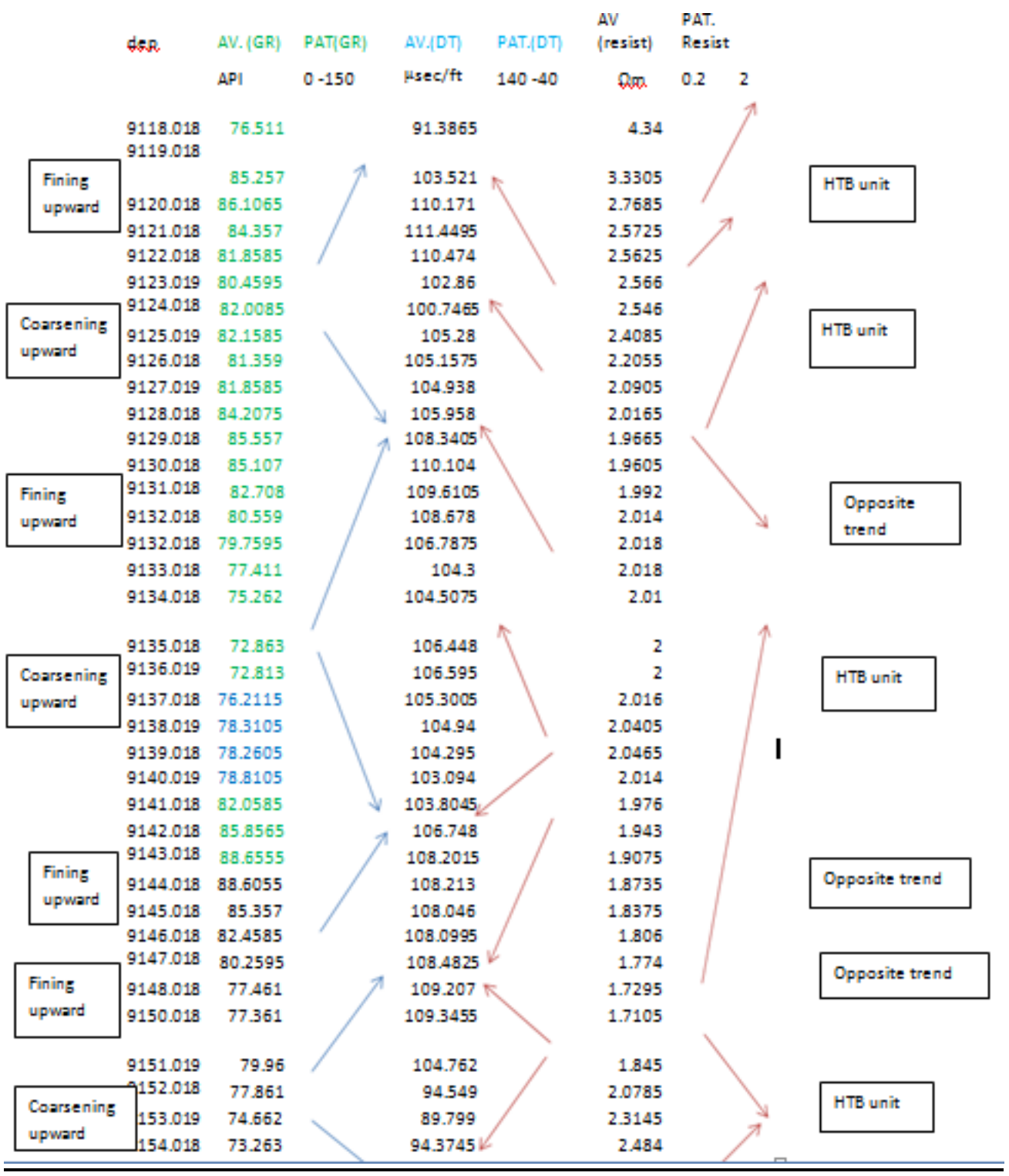

Table 3: Sequences (using TOC) in Shale Section 9161-9118ft at Pologbene-001 


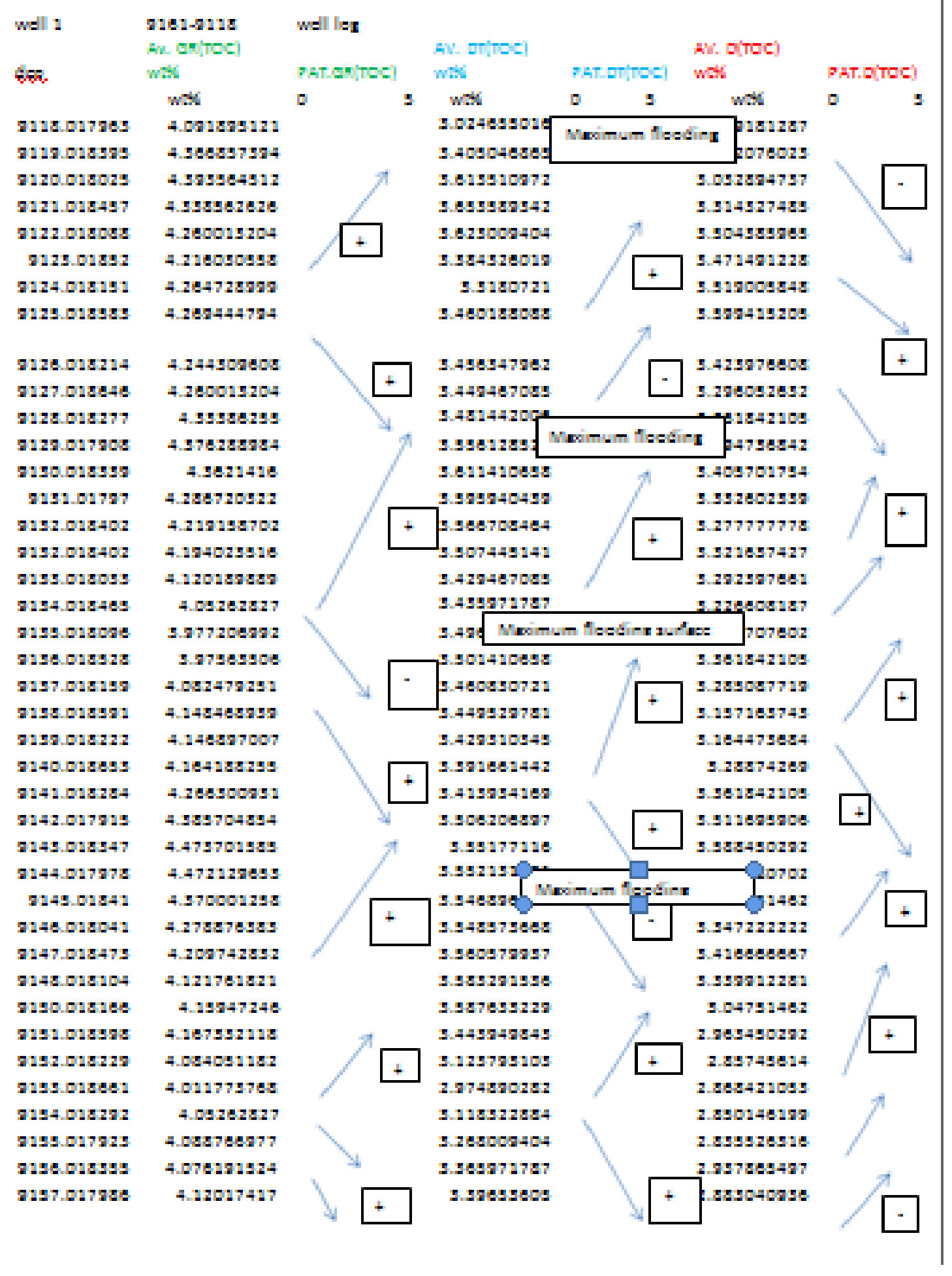

www.scirj.org

C 2021, Scientific Research Journal http://dx.doi.org/10.31364/SCIRJ/v9.i10.2021.P1021886

This publication is licensed under Creative Commons Attribution CC BY. 